\title{
ATTITUDES OF GENERATION Y TOWARDS LUXURY PRODUCTS AND YOUTH-LED CHANGE IN LUXURY CONSUMPTION BEHAVIOUR
}

\author{
Belgin Yazic1 \\ İstanbul Kültür University, Turkey \\ b.yazici@iku.edu.tr
}

\begin{abstract}
To many people luxury products were once considered hard to access and a privilege to use. Luxury used to mean a product or service only accessible by a small group of people, a product or service that was scarce (Nueno \& Quelceh, 1998). However, luxury products have now become more affordable to more consumers, especially for consumers from the middle class who access more money than ever before (Hauck \& Stanforth, 2007) and therefore luxury brands have the chance to flourish and establish their reputation worldwide. In order to do so, they must truly understand their consumers and recognise how they are changing. Besides the drivers of their decisions, the purchasing behaviors of consumers are evolving. Consumers prefer to be engaged with digital channels in terms of their buying processes. Generation $\mathrm{Y}$ has a tremendous impact of the world economy because of the number of its representatives and increasing purchasing power, so it has been transforming into the biggest consumer segment throughout history. As a result of this, Generation $\mathrm{Y}$ attracts the attention of many scientific fields from psychology to economics. The main question is what makes this generation so unique both as a research topic for scientific studies and a marketing challenge. Young adults who were born between 1980 and 1990 are considered to be Generation Y and this generation has ended up to become the largest part of global consumer market and it has become an undeniable fact for luxury brands that their motivations and attitudes have to taken into consideration in the process of developing products. The brands need to communicate with the representatives of Generation Y effectively. The aim of this article is to examine Generation Ys' attitudes, i.e. their beliefs, feelings and purchase intentions towards luxury products and the meanings of the word "luxury" to young people, reasons for buying luxury products, and, on a small scale, young adults' luxury brand awareness and brand loyalty. In addition, this study aims at not only examining Generation Y customers' luxury purchasing behaviour but also helping organizations understand such customers' needs and wants. It is widely acknowledged that understanding consumer behavior is the key to be successful in business and this youth- led change in luxury consumption behavior should not be underestimated to be able to attract the attention of the future powerhouse of the global economy.
\end{abstract}

Keywords: Generation Y, millenials, luxury consumption, luxury brands, new luxury, luxury marketing, Generation Henry.

\section{Y KUŞAĞININ LÜKS ÜRÜNLERE KARŞI TUTUMLARI VE GENÇLERINN ÖNCÜLÜĞÜNDE LÜKS TÜKETIM DAVRANIŞLARINDAKİ DEĞIŞSiM}

\section{ÖZ}

Geçmişte, çoğu insan, lüks ürünleri erişilmesi zor ve kullanımı bir ayrıcalık olarak değerlendirirdi. 'Lüks' kavramı, yalnızca az sayıda insanın erişebiliceği bir ürün veya hizmet anlamına gelirdi ve ayrıca bu ürün ve hizmet az sayıda veya oranda bulunurdu (Nueno \& Quelceh, 1998). Fakat, lüks ürünler günümüzde, tüketiciler, özellikle daha önce hiç kazanamadıkları kadar çok para kazanabilen orta sınıf tüketiciler, için daha makul fiyatlıdır(Hauck \& Stanforth, 2007). İşte bu nedenle, lüks markalar, küresel olarak büyüme ve itibar kazanma imkanı bulmuşlardır. Bu amaçlara ulaşma adına, lüks markalar tüketicilerini gerçek anlamda anlamalı ve tüketicilerin yaşadıkları değişimleri fark 
etmelidirler. Tüketicilerin aldıkları kararları etkileyen faktörleri ek olarak, alım davranışları da evrim geçirmektedir. Tüketiciler, satın alma süreçlerine dijital kanallar aracılığıyla bağlı kalmayı tercih ederler. Y jenerasyonu hem artan sayıları hem de satın alım güçleriyle tarih boyunca ortaya çıkmış en büyük tüketici segmenti haline gelmişlerdir. Bunun sonucunda, Y jenerasyonu psikolojiden iktisada bir çok alanın ilgisi çekmektedir. Asıl mesele, bu jenerasyonu hem bir bilimsel araştırma konusu hem de bir pazarlama sorunsalı olarak ortaya çıkaran faktördür. 1980-1990 yılları arasında doğan genç yetişkinlere $Y$ jenerasyonu denmektedir ve bu jenerasyon, tüketici pazarının en büyük parçası haline gelmiştir. Lüks markalar için bu jenerasyonun motivasyonlarını ve davranışları ürünlerini geliştirirken dikkate almak yadsınamaz bir gerçek haline gelmiştir. Lüks markalar, Y jenerasyonu ile etkin bir iletişime girmek zorundadır. Bu makalenin amacı, Y jenerasyonunun tavırlarını, örneğin inaçlarını, hislerini ve lüks ürünlere yönelik satın alma niyetlerini ve "lüks' kelimesinin bu jenerasyon için çağrıştırdığı anlamlarını, lüks ürün alma sebeplerini ve küçük ölçekte genç yetişkinlerin lüks ürün farkındalıklarını ve marka sadakatlerini incelemektir. Buna ek olarak, bu çalışma yalnızca Y jenerasyonu müşterilerinin lüks tüketim alışkanlıklarını incelemeyi değil kurumlara bu müşteri grubunun ihtiyaç ve isteklerini anlamada yardımcı olmayı amaçlamaktadır. İş hayatında başarılı olmanın yolunun tüketici davranışlarını anlamaktan geçtiği geniş kabul gören bir olgudur ve eğer küresel ekonominin gelecekteki dinamosunun dikkati çekilmek isteniyorsa, bu genç grubun önderliğinde lüks tüketim davranışlarında yaşanan değişim hafife alınmamalıdır.

Anahtar Kelimeler: Y jenerasyonu, Milenyum kuşağl, lüks tüketim, lüks markalar, yeni lüks, lüks market, Henry jenerasyonu.

\section{INTRODUCTION}

People watch television, flip through magazine or newspaper pages, surf on the Internet. While they are doing all these they are exposed to many images of rich and famous people and these images refer to their emotional needs. Such needs are relatively important these days since people want to feel beautiful, important and recognized more than any time throughout history. Rich and famous people like to show their earthly possessions such as clothes, cars and houses. They also make ordinary people feel that their lifestyle and possessions make other people become part of their world. The only thing that ordinary people need to do is to purchase the right goods or products used by the rich and famous. Then, ordinary people start to buy Louis Vuitton bags or Chanel glasses and become addicted to such goods. This addiction is called "brand loyalty."

Fashion has always had a crucial role in great civilizations such as the Egyptian, Greek and Roma throughout the history. Latest fashion apparel, cosmetics and accessories were key factors to show status in society. In parallel to this fact, the consumption of luxury products was only limited to elite classes of society together with clear cut differences between social classes. At the beginning of the $19^{\text {th }}$ century, luxury goods sector appeared with valuable luxury brands that still exist today such as Hermes, Cartier and Louis Vuitton in France and Burberry in England. (Haataja, 2011)

The luxury goods sector has transformed in recent decades. Initially, two indispensable parts of daily life in post-modern times, globalization and the Internet, have lowered the barrier to enter the luxury sector which was put centuries ago for the big masses. This could be named as the "democratization of luxury". This process could be explained as the creation of a period when luxury goods are accessible for an increased number of consumers. The term 'masstige' was coined for the luxury market which is a combination of 'mass' and 'prestige'. Nowadays, it is easier for masses to access luxury sector. (Okonkwo, 2007).

Deloitte's David White, who is also a retail industry leader, comments that the characteristics that mark the borders of luxury sector are fading and will continue to disappear in the future. For instance, luxury consumers who travel a lot changed the concept of national boundaries. Luxury consumers who are interested in technology make global luxury brands to keep with the date. Global luxury brands are required to maximize the engagement level of the digitally-savvy, time sensitive and socially aware consumers, otherwise they are bound to fall behind. 
The Millenials, who are also called Generation Y, play a crucial role in the development of the luxury sector in the future. Almost two thirds of the millennials go online to search information about luxury products. One third of them use social media for discounts and promotions of luxury items. However, only one out of ten older luxury consumers use social media for discounts and promotions. Generation $\mathrm{Y}$ is emerging as leaders in technology and they are expected to become three fourths of the global workforce by $2025^{1}$. When all these considered, it isn't difficult to understand that luxury brands need to understand the buying habits of Generation $\mathrm{Y}$ and the changing meaning of luxury - the new luxury ${ }^{2}$.

\section{THE CONCEPT OF LUXURY}

There isn't only one way to define luxury. Actually, it isn't easy to define luxury since the concept has many vague parts due to the significant changes in the sector. These changes make researchers think about the new perspectives of what a luxury item is. It is an undeniable fact that the definition of luxury varies depending on a person or situation. Therefore, it is impossible to come up with a universal definition for the concept of luxury. According to Brun \& Castelli (2013), wealth, power and exclusivity have always been linked with luxury goods. According to Oxford Dictionary (2014), luxury is 'a state of great comfort or elegance, especially when involving great expense. It can inferred from both definitions that price plays a crucial role in defining luxury and when it something comes at a great expense it is considered as luxury.

Luxury goods have the highest price/quality relationship. In this equation, quality means the functions of an object that are measurable and tangible. However, this definition is criticized by some researchers such as Jean-Noël Kapferer. According to Kapferer, what matters is the comparable functions. He states that upper-range products could be defined as tangibles associated with a specific product category, while luxury products are intangibles associated with values and ethics. Luxury products provide additional pleasure and flatter senses. (Kapferer, 1999)

According to Wiedman, et al. (2007), luxury goods are not affordable by everyone. When something is not afforded or owned by the majority of people, then it is likely to be rated as luxury. Kapferer suggest that in postmodern societies, everyone has been given a right to access luxury. In fact, this perception is totally opposite with the old one in which only upper class people have the right for luxury goods. (Kapferer, 2012)

When upmarket products are considered, according to Prendergast \& Wong (2003), quality is a more important criteria than price. Luxury brands need to be aware that for upmarket consumers what matters is the quality not the price. Mintel (2011) suggests that there might be challenges as prices increases and economic crisis. However, well-positioned innovative product launches encourage consumers to splurge. Wilson (2014) argues the 'lipstick effect, which explains the wish of consumers to buy unnecessary products as lipsticks and chocolate in the time of social and economic crisis. This explains the concept of luxury and symbols of to judge quality of someone's life in the mind of consumers.

\section{WHAT IS THIS SO CALLED "NEW LUXURY"?}

Luxury goods market has grown significantly in the past decade. This growth could be linked to the trend of "democratization" of products and brands. This trend is so powerful that products and brands that used to highly exclusive are now consumed by masses. In order to exemplify that American middle-market consumer could be observed since, very recently, they have started to trade up and actually afford the upmarket products and brands. New luxury is not out of reach for the masses though it still has higher levels of quality and taste than the ordinary products in the market. (Silverstein \& Fiske 2008, 1-2)

\footnotetext{
${ }^{1}$ Deloitte Touche Tohmatsu Limited's (DTTL) 2014 third annual Millenial Survey

2 Deloitte's Luxury Consumption among European High Earners 2014 survey
} 
As mentioned above, new luxury is not out of reach for the masses, but traditional luxury was. Brands and products of traditional luxury were only consumed by a very limited group of top-earning people because all brands and products which belong to this category were priced to target only a very small number of people. Very limited number and uniqueness of the kind justifies the high pricing procedure of these products. Luxury used to mean a sense of elitism, but not emotions. Silverstein claims that new luxury appeals to emotions. A powerful emotional engagement is possible to develop with new luxury products. For instance, Chanel bags are based on class and exclusivity, not emotions. Consumer are attracted to this conventional luxury product for price without any emotions. (Silverstein \& Fiske 2008, 4-6, 55-56.)

Since, today, there is a wider range of products, even in the same category, the price of goods vary. However, the volume of new luxury goods is much higher than conventional ones, which leads to lower prices of new luxury products than traditional ones. When the volume of products decrease, prices increase. What luxury brands do in order to reach masses is to stretch their brands by including lower-priced products into their ranges. From cosmetics to interior decorations, this trend stands. (Okonkwo 2007, 237.)

Table 1 below shows the differences between old and new luxury and conventional goods: (Silverstein \& Fiske 2008, 56.)

\begin{tabular}{|c|c|c|c|}
\hline & NEW LUXURY & CONVENTIONAL & OLD LUXURY \\
\hline Affect & Engaging & Bland & Aloof \\
Availability & Affordable & Ubiquitous & Exclusive \\
Price & Premium & Low cost & Expensive \\
Quality & Mass artisanal & Mass produced & Handmade \\
Social basis & Value driven & Conformist & Elitis \\
& & & \\
\hline
\end{tabular}

Maslow's Pyramid of Needs is used in order to compare and contrast old and new luxury with the aim of showing the changes and explaining the evolving consumer products by creating a new pyramid.

Table 2: Evolving Consumer Constructs: Ego Gratification (Miller, 2015) 


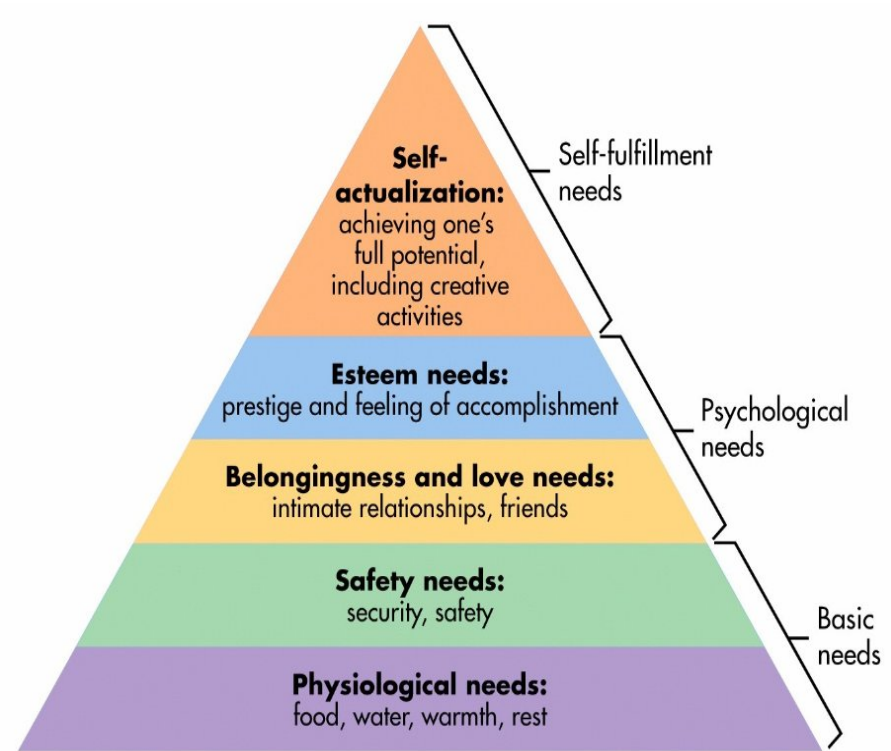

OLD: Maslow's Pyramid of Needs (Maslow, 1943)

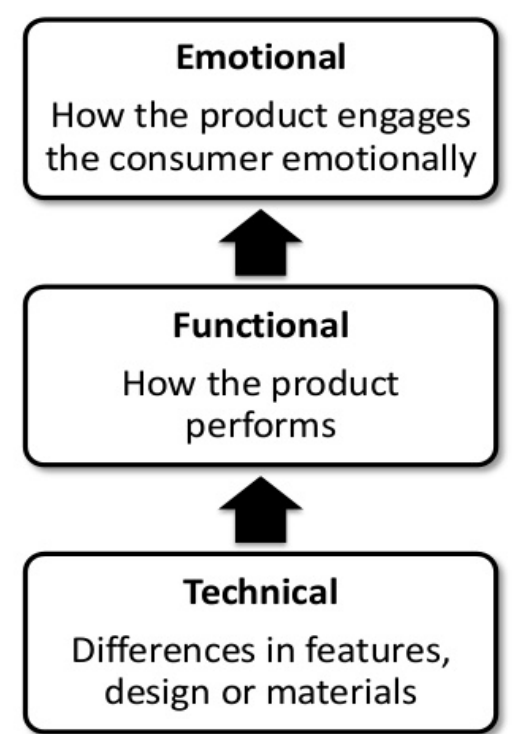

NEW: Luxury Ladder of Benefits (Silverstein et al, 2013)

Especially, after the end of the Cold War, the world has been globalizing at an ever-increasing pace, which has led to more economic activities followed by prosperity. Prosperity resulted in social democracy. The reason why the two is crucial is that they resulted in the boom in the luxury industry. Luxury, once, meant segregation among classes. There were dark and thick lines between people from different social and economic backgrounds. Today, these thick lines have mostly faded away and 'free movement' among classes is possible. Therefore, enjoying luxury is no more unique to a limited group of people. Digital and social communications, relocation of the wealth, at least to a certain extent, changing profile of the rich made the problem of accessibility to luxury disappear and increased the joy experienced by people with new luxury.

Jean-Noël Kapferer claims that new luxury is a sensory experience. Cars used to be luxury in the beginning of the century since they were scarce, now car is not important since what matters is the brand. In fact, the expectations of consumer transform when they are provided with the products of new luxury. It is a mutual process in which both sides affect and are affected from each other. On top of that, the feeling of right to luxury leads to changes in the whole market.

Many factors have been actively involved in the process of change in the luxury market. However, there is one more factor to consider which is Generation Y. In the Western World, 'traditional luxury consumers' from high class and 'new luxury consumers'. They, new premium consumers, mainly differ in their attachment to the brands they consume, but it is not easy to segment latter (Hujic, 2005)since they are not part of single culture or social class, which means that they are beyond the dark thin lines mentioned above. (Okonkwo, 2007, p.38)

It is hard to characterize new luxury consumers because they do not seem to have post modernistic tendencies. How they look and sound is that they are young or feeling young in spirit, professional, modern, eager to be recognized with high expectations, willing to get personal pleasure and in essence eclectic. (Chevalier and Bastien, 2008)

An expert on the psychology of American luxury consumers, Pamela Danziger, the young but also rich people who belong to Generation X and Millennial Generation will definitely be in the key position from which global luxury marketers take reference to decide on their strategies for the next two decades. National borders are fading away with the Internet and new media as a result the socalled 'global village' of international luxury market will be driven by the needs and tastes of the young affluents. (Danziger, 2004.) 


\section{CHARACTERISTICS OF GENERATION Y}

Any individual born between the years of 1980 and 2000 are referred to Generation Y (Gen Y). They are no different than other generations in terms of the factors that have shaped them. Leaders and social, political and economic developments of their time have fed this shaping process. Gen Y people are also called Echo boomers since they are the children of baby boomers who were born between the years of 1946 and 1964. Net generation and Millenial generation are other terms to specify Gen Y. (Erickson, 2008) Gen Y is special since they have grown up with a mutual respect to each other and the feeling of being equal as boys and girls (Orrell, 2007). This was never a common practice. In the US, this generation is known to be the most-cross cultural, cross-creed and cross-color generation in history. Racial, ethnical differences and sexual orientation are no more barriers among this group since they are open-minded and they accept diversity.

Gen Yers have had the opportunity to access technological innovations since their childhood and used all sorts or media including social media which had lead them to be techno-savvy and independent(Martin \& Tulgan, 2001). They have become entrepreneurial using this new way of communication that made them a part of the globalized world with their eagerness to be flexible. (Lancaster \& Stillman, 2002)

Idealistic Boomer parenting style and the influence from the Tradionalists have made Generarion Yers become optimistic and confident and loyal to institutions together with the feeling of skepticism to be cautious. What is more, they are "realistic" in all senses. (Lancaster \& Stillman, 2002)

According to Gravett \& Throckmorton (2007), this generation has a very different perspective on many things such as:

- extreme awareness of the environment, worrying about our future, locally and globally, and active engagement in recycling and reducing wastes or pollutants;

- being a diverse generation with an open mind and acceptance for differences in race, gender, ethnicity, sexual orientation;

- an expressive generation as evidenced by some of their dress, body jewelry, and brightly colored hair;

- being very socially conscious and committed to any cause they value and demonstrating that through volunteering.

- and having solid moral standards, being much more against premarital and unprotected sex, alcohol, and drugs than Baby Boomers or Gen Xers.

In the table below, common traits to define Gen Y have been listed. (Kane, 2011)

\begin{tabular}{|c|c|c|c|c|c|c|}
\hline Tech-savvy & Like to socialize & $\begin{array}{l}\text { Information- } \\
\text { driven }\end{array}$ & Selective & $\begin{array}{l}\text { Family- } \\
\text { Centric }\end{array}$ & $\begin{array}{l}\text { Achievement- } \\
\text { Oriented }\end{array}$ & $\begin{array}{l}\text { Team- } \\
\text { Oriented } \\
\text { and } \\
\text { Attention- } \\
\text { Craving }\end{array}$ \\
\hline $\begin{array}{l}\text { - Key driver } \\
\text { for Gen Y } \\
\text { - Gen Y have } \\
\text { great access } \\
\text { to } \\
\text { information } \\
\text { and options } \\
\text { - Life } \\
\text { without } \\
\text { technology is } \\
\text { unthinkable } \\
\text { - Gen Y } \\
\text { people are } \\
\text { more }\end{array}$ & $\begin{array}{l}\text { - Gen Y people } \\
\text { love to post their } \\
\text { lives online } \\
\text { - Continuous } \\
\text { sharing of } \\
\text { knowledge and } \\
\text { information } \\
\text { through social } \\
\text { media affect } \\
\text { their decision- } \\
\text { making process } \\
\text { - Gen Y is } \\
\text { connected } 24 / 7\end{array}$ & $\begin{array}{l}\text { - Gen Y people } \\
\text { are information- } \\
\text { driven } \\
\text { - They search, } \\
\text { make } \\
\text { comparisons } \\
\text { using the } \\
\text { Internet } \\
\text { - They receive } \\
\text { information } \\
\text { from different } \\
\text { channels } \\
\text { - They shop } \\
\text { online }\end{array}$ & $\begin{array}{l}\text { - Gen Y have } \\
\text { high } \\
\text { standards for } \\
\text { quality } \\
\text { - They are } \\
\text { selective and } \\
\text { demanding } \\
\text { in shopping } \\
\text { - They } \\
\text { compare and } \\
\text { contrast } \\
\text { products } \\
\text { before } \\
\text { buying }\end{array}$ & $\begin{array}{l}\text { - They } \\
\text { demand a } \\
\text { better } \\
\text { work/life } \\
\text { balance due } \\
\text { to the } \\
\text { importance } \\
\text { they } \\
\text { attribute to } \\
\text { family life }\end{array}$ & $\begin{array}{l}\text {-They have } \\
\text { high } \\
\text { expectations } \\
\text { from their } \\
\text { employers } \\
\text {-They are } \\
\text { forward } \\
\text { thinkers } \\
\text {-They demand } \\
\text { challenging } \\
\text { and } \\
\text { meaningful } \\
\text { tasks from } \\
\text { their superiors. }\end{array}$ & $\begin{array}{l}\text {-They value } \\
\text { teamwork }\end{array}$ \\
\hline
\end{tabular}




\begin{tabular}{|l|l|l|l|l|l|}
\hline $\begin{array}{l}\text { proficient in } \\
\text { technology } \\
\text { than any } \\
\text { other } \\
\text { generation } \\
\text { ever }\end{array}$ & $\begin{array}{l}\text { - They use social } \\
\text { media to make } \\
\text { decisions about } \\
\text { online shopping }\end{array}$ & $\begin{array}{l}- \text { They } \\
\text { demand } \\
\text { functionality } \\
- \text { They often } \\
\text { change jobs } \\
\text { and become } \\
\text { aware of } \\
\text { career } \\
\text { success } \\
\text { stories }\end{array}$ & & praise at work \\
& & & \\
& & & \\
\hline
\end{tabular}

\section{LUXURY CONSUMPTION BEHAVIOR OF GENERATION Y}

The New Luxury Millennials or Generation Y are born between 1980 and 1999 and they are a collaborative, creative and entrepreneurial group who will drive global luxury industry growth over the next decade. This group who was brought up by wealthy parents during the lively, globalized and consumerist 1990s observed the birth of the Internet and its associated digital wonders, and has become one of the most brand-savvy generations to reach maturity so far. Generation $\mathrm{Y}$ is interested in brands to have a past and a story, but they prefer to engage with this story on interactive digital platforms, as well as in stores.

According to the Luxury Institute, almost two-thirds (60\%) of Millennials read user-generated product reviews when shopping for luxury goods, $55 \%$ learn about products in-store but prefer to purchase online, and $18 \%$ recommend luxury brand purchases through their social network sites. Also, according to American Express Business Insights, millennials account for 31\% of all luxury spending online which makes up a larger proportion than Generation $X$, who represent $23 \%$, and Baby Boomers, who make up 19\% (AdAge Insights, 2012).

Generation Y make their first contact with luxury brands online, and mobiles are their virtual tools of choice. According to the global research published by Inmobi in February 2013, Millennials spend on average 7.2 hours a day consuming media content, with more of that time spent consuming it on mobiles than any other channel, including TV or laptops. 54\% of this generation use their mobile phones as their main way of access to the internet. The same research shows that $69 \%$ of Millennials spend money on an activity via mobile phones and $83 \%$ plan to conduct mobile commerce in the next 12 months (Solomon, 2014).

Thanks to their strong grasp of social media, Generation Y use peer-to-peer pressure on the luxury purchasing decisions of their fellow Millennials. About $70 \%$ of them recommend their favorite brands online and $47 \%$ have criticized a brand, according to research by PR agency Edelman. ${ }^{3}$

Generation $\mathrm{Y}$ is attracted to trends and is quick to adopt the latest technology and fashion like the generations that came before them. Gen $\mathrm{Y}$ is also seeking out the authentic, the unique and the exclusive. Classic brands like Ray-Ban, Levi's, Volvo, Chanel and YSL have enjoyed a resurgence over the past decade. "As a result of the recession, one of the biggest shifts is that people are more drawn to classics that will always look amazing, but never be considered excessive," said Sara Bamossy, a media planner with Saatchi \& Saatchi in New York. "No one wants to be seen as a showoff." Authenticity and self-expression are other factors that drive this generation. "This group is drawn to products they feel are "ever-cool," said Bamossy. A member of this generation, for example, may drive a beat-up Toyota pickup truck worth $\$ 3,000$, but use the vehicle to carry around a $\$ 10,000$ mountain bike. "They are selective in being excessive, and will spend money on things that are most important to them - not necessarily things that are the latest trend," she said. (AdAge Insights, 2012).

\footnotetext{
${ }^{3}$ The Gold Paper. New Millenial Luxury. Retrieved from http://gold-paper.somewhat.cc/gold-paper-book.pdf.
} 
This group is also drawn to revived brands. For instance, Burberry is perceived as a wild success among Generation $\mathrm{Y}$ because in addition to its commitment to its heritage design and quality it is given an updated look and dedication to reach younger markets with social media. "Younger consumers are drawn to quality and authenticity, and things that are true to what they are and owning it," said Maya Draisin, Wired's associate publisher of marketing. "They define that to being what is true to what it is, knowing who you are and owning that-even they own it in a new way. Burberry didn't diverge from who they are, but put out a new look." (AdAge Insights, 2012).

Nostalgia is another theme which explains how heritage brands like Louis Vuitton, Chanel, Lacoste and BMW dominate the luxury brands which are purchased by Generation Y. Wired's Draisin said in a high-tech, ever-evolving marketplace, tech-savvy consumers prefer products with a sense of history. "People are so entrenched with the future, they need something to ground them," said Draisin. She pointed to the annual Wired pop-up created in New York every holiday season to showcase new gadgets and technology. "Every year, the collection has a nod backwards," she said (AdAge Insights, 2012).

Saatchi \& Saatchi's Bamossy said for this group, products that make specific sense to the user has significant importance. One example: younger members of affluent Generation Y who have a $\$ 900$ payment on a new Audi, but a $\$ 500$ rent payment because they live in a shared house with friends and have no expenses associated with a spouse or children. "They are willing to spend money on products they will use and that will make their lives better and that does not rule out the inexpensive," said Bamossy (AdAge Insights, 2012).

Expectation of transparency and ethical identity from luxury brands plays an important role owing to easy access to online information and the growth of blogger culture. Some brands such as H\&M now publishes full details of its supply chain. Generation $\mathrm{Y}$ is a very confident group in its opinions and they also have higher expectations. Since this group is the Google generation, they feel they have the power to find out any kind of information and they feel they are more expert than the marketers and salespeople themselves. Luxury brands that have combined the in-store experience with Generation Y's reliance on online information have shown an appreciable success in this challenging sector.

Generation Y travel experience is also shaped by digital technology from online research, booking and checking to smartphone application searches to find places. According to research published in 2013 by The Boston Consulting Group, Millennials use travel applications on their smartphones more often than other generations and rely more on user reviews, experiences and online content when booking travel or hotels. Hilton brand Conrad's new downloadable Conrad Concierge application and tablet control of lights and room temperatures at The Peninsula Hong have been appreciated by Generation Y travelers. Another example is W Hotels whose application enables consumers to check local weather, download curated music mixes, receive hotel event updates and order room service. (Barton et al, 2013)

\section{GENERATION HENRY: HOW GENERATION Y IS REDEFINING LUXURY?}

Henry is the new word which is being used in luxury market to define new luxury consumers. It means "High Earner, Not Rich Yet" consumer. They say that luxury consumers have evolved from high-net-worth shoppers with lavish penthouse condos and fat investment portfolios to consumers with a steady cash flow, but little accumulated wealth. High Earners, Not Rich Yet (HENRYs) are young, usually well educated, and highly paid but have not accumulated significant wealth yet. The nickname goes back to a 2003 article in Fortune magazine that described families with incomes between $\$ 250,000$ and $\$ 500,000$ but they were cash poor because of their affluent lifestyles (Tratt, 2015). ${ }^{4}$ According to Lindsay Rowe, who is Vice President of Client Engagement and Strategy at PBJS, (a full-service experiential agency with in-house creative, production, digital and video) "HENRY" the luxury shopper has changed the luxury category,

\footnotetext{
${ }^{4}$ https://www.luxurydaily.com/henrys-can-help-high-end-marketers-rethink-definition-of-millennials-andluxury-itself/
} 


$\begin{array}{rll}\text { Brand Position: } & \text { FROM } & \text { TO } \\ \text { Purpose of Spend: } & \text { Exclusive } & \text { Unique } \\ \text { Bragging Rights: } & \text { Acquiring } & \text { Experience } \\ \text { Shopping From: } & \text { Brand } & \text { Back-Story } \\ \text { Shopping Influence: } & \text { Spontaneous } & \text { Considered } \\ & \text { In-store } & \text { Digital }\end{array}$

Many of today's Millennial luxury shoppers fall into this consumer group and that's the definition they use to explain how and why the luxury category is changing.

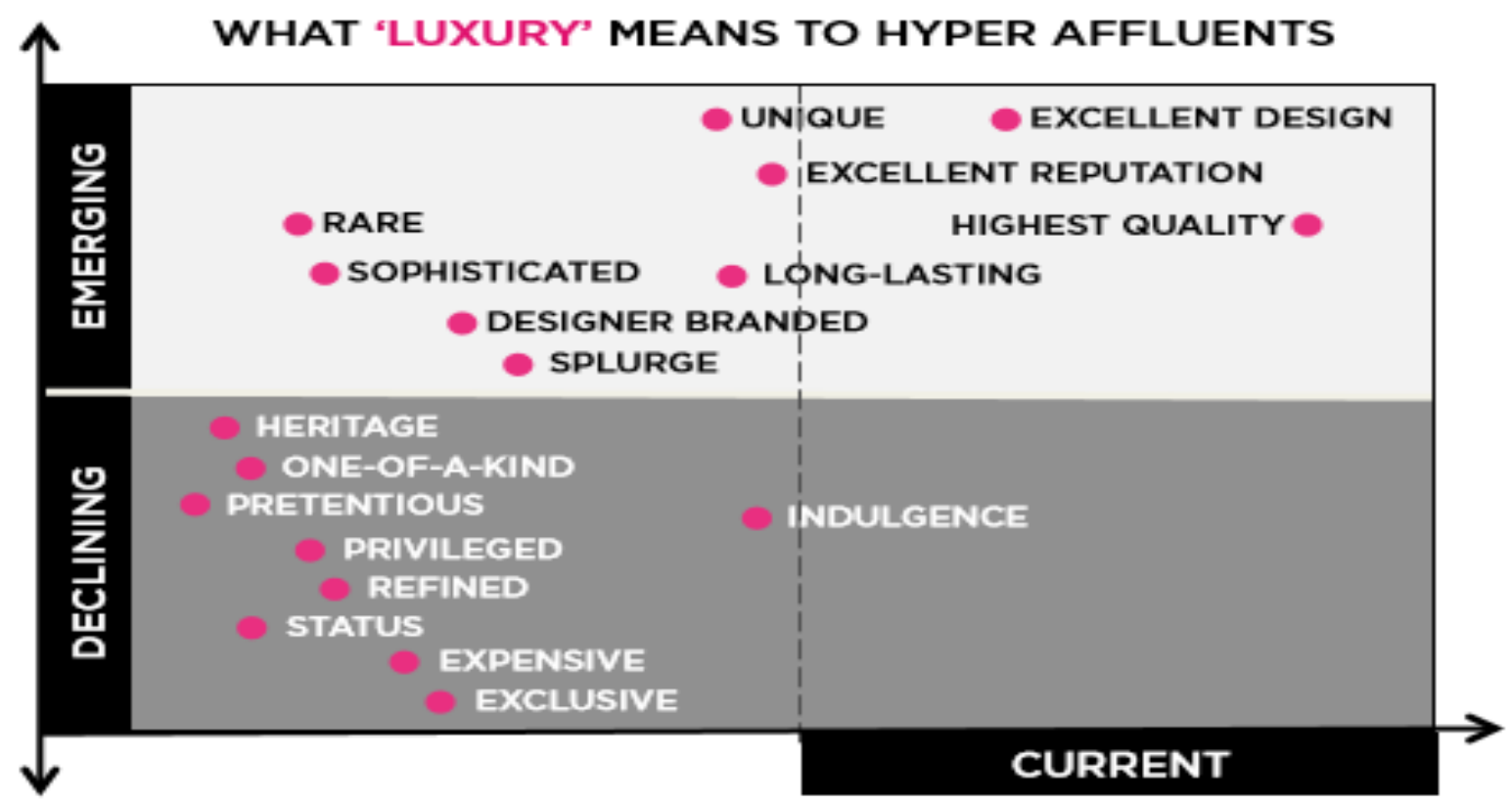

Table 3: What Luxury Means To Hyper Affluents? (Sources: Ipsos Media CT) ${ }^{5}$

Tangible items are the way that younger consumers use to value experiences. Putting a premium on experiences and finding opportunities to post a share-worthy story or desirable experience to boast on social media are the things that they are looking for. It's called the new social currency. Millennial consumers don't want to define themselves with the things they buy as they don't see their purchases as achievements or trophies in the way former generations did. Instead, they prefer to collect memories like merit badges and they are actively looking for unique experiences (Danziger, 2011).

As a result, there is no doubt that we're experiencing a new evolution of the term "luxury." It no longer refers exclusively to purchases such as handbags or jewelry. Now, it includes high-priced farm-to-table foods and craft beers, as well as pricey experiences such as travel. PBJS agency mentions three emerging luxury categories while explaining the new luxury consumers. ${ }^{6}$

The first one is "The Technophile Shoppers". With the digital age, consumers are beginning to purchase luxury brands online. Younger consumers are more likely to shop online than any other groups. In the last 10 years, though, luxury rental companies such as Rent the Runway and Bag, Borrow, or Steal have been appearing on the Internet by allowing consumers to rent luxury items temporarily instead of purchasing them, which can be surprising for the luxury goods business.

\footnotetext{
${ }^{5}$ MSLGroup PBJS. Millenials \& The New Luxury. Retrieved from http://www.slideshare.net/PBJS/millennialsthe-new-luxury.

${ }^{6}$ MSLGroup PBJS. Millenials \& The New Luxury. Retrieved from http://www.slideshare.net/PBJS/millennialsthe-new-luxury
} 
The second one is "The Luxury Dabblers". While most of the Millennials prefer a modest lifestyle with fewer possessions, they are still choosing to spend their money somewhere. When Baby Boomers first introduced the luxury market, they spent all of their money and never looked back. Products were luxury because they were expensive and expensive because they were luxury, they didn't question anything. Millennials, on the other hand, have become a generation of Luxury Dabblers. They don't need to own things because luxury brands don't show who they are. They are happy to dabble in luxury brands and experiences. If they feel it's something they deserve, they think it is worth the cost and allows them to keep a mainstream profile.

The third consumer type is "The All-Access Fans". According to PJBS agency, only one in two consumers agree with the statement "Owning things is a good way to show my status in society." Four in five consumers agree that there are sometimes real advantages to renting over owning, and adults ages 18 to 24 are nearly twice as likely as those ages 25 and older to say that access is the new ownership. When it comes to luxury, young consumers today care about quality and accessibility.

In today's market, Millennials' tendency to discover new brands, high-quality goods and a company's heritage make them natural luxury consumers. Since they do in every aspect of their lives, Generation $\mathrm{Y}$ do not accept something on face value. They love a good backstory and prefer to have a strong desire for authenticity. However, luxury items or experiences must have a functional, performanceoriented reason for its higher cost, which enables them to justify a purchase.

\section{HOW TO ENGAGE THE FUTURE LUXURY CONSUMERS GENERATION Y?}

The factors that shape Generation Y's consumption behavior are very different from the Baby Boomers because Baby Boomers grew up in a period when conspicuous consumption was appreciated. However, Generation Y has grown up during a time when a "green" worldview has become prevalent, and terms like "sustainability," "organic," "fair trade," "authenticity" and "artisanal" have gained importance and earned respect. Generation Y is also the generation that was brought up with praise. That's why they are generally willing to record their achievements and get their rewards for doing so, which can be a "like" or "check-in".

This generation has grown up during an age when they had a VCR and a DVD player in their houses, they can use ATMs to have cash and they can access information, music, movies and TV whenever they want thanks to the internet, which is generally free. Therefore, this generation is used to getting what they want immediately and as consumers if they are told to wait they most likely disdain this behavior. In contrast, we can see that their childhood was full of releases of must-have items which coul be obtained by lining up to wait Power Rangers, Pokémon, the next Harry Potter book or the latest Call of Duty video games. If a product wants to engage this generation, their products should provide an exclusive experience or give this group bragging rights, then they will queue up to be among the first to purchase that product. Apple has taken advantage of this trait quite well. These are traits that to be considered carefully when crafting luxury marketing programs and messages which aim at Generation Y. (AdAge Insights Trend Report, December 2012)

Many luxury marketers have renovated their brands to be able to attract this younger, affluent group. To engage this group, some legacy brands like Burberry, Saks Fifth Avenue and BMW have made improvements to their products and formed their marketing strategies and all of them resulted in success. However, when we look at their traits and the technology we can say that many more opportunities abound.

Many people who are interested in Generation $\mathrm{Y}$ and their consumption behavior claim that Millenials are the most difficult group that marketers can attract and retain, which leads to discussions on brand loyalty of this generation. (Lazarevic, 2012). Generation Y has low a very low loyalty towards brands because closeness to their location is more important for them while choosing a store to purchase. (Parment, 2013). On the other hand, they are very loyal to some brands of clothing, personal care objects or cars, if these brands are popular and if these products say something about the person that 
uses those brands (Noble et al., 2009). That means the personality of the brands should reflect the consumer personality of the Millenials, which gives consumers a high degree of comfort (Muhammad and $\mathrm{Ng}, 2002$ ). Hence, if companies would like to inspire trust to the Millenials, they need do reposition their brands accordingly and the can assure $\mathrm{Y}$ consumers that they deserve to be purchased. (Pine and Gilmore, 2002). Within this framework, according to studies, the brands which are good at creating a relationship with the Millenial consumers via interaction and personalized messages are among the most successful brands (Talbott, 2012). Thanks to the technology and new virtual world, establishing close relationships is not too difficult as long as they adopt an experienced based marketing strategy (Kim, 2001). It is also a common idea that Generation see shopping as a form of sport (Schewe and Meredith, 2004). The brands should offer practical recreational experiences related to fun and entertainment. For example they can organize some events where they may invite sport stars or famous TV personalities that promote a certain brand or product (Sullivan and Heitmeyer, 2008).

Because of the developments like "democratization of luxury" or "masstige" in luxury sector, luxury brands are mainly preferred by wealthy people who are under 35 and as a result of this, marketers are encouraged to use social media which is the common communication way being used by this generation. Thus, social media tools have become one of the most important strategies that are being used by luxury brands to be able to engage luxury consumers.

When we look at the success stories of luxury brands, we can see Burberry as one of the most successful ones. What made Burberry successful was undeniably its decision to be the first luxury brand to invest in digital communications, and social media and also it repositioned its brand as a 'cool and trendy' and increased its appeal to younger and tech-savvier Generation Y consumers. Young consumers are the future of all fashion brands and Burberry knows "how" to speak to them directly through social media. Burberry has nearly 18 million followers on Facebook and nearly 4 million followers on Twitter. Burberry has lead the way in terms of digital innovation in the luxury and fashion sector for a while now, and these new improvements strengthens its position as the most innovative luxury brand on the market. In 2012, Burberry created 'Burberry World Live' which was designed to mirror their website providing an exclusive experience. Instead of cash registers, payments were made on devices with members of staff floating around the store. (Kontu ve Vecchi, 2014) Burberry's belief is that people may not be ready to buy Burberry but that shouldn't mean that they should not be welcomed. It proves that using multimedia and digital is the best way to stay in touch without hard-sell strategies.

Another success story belongs to Lacoste. Four years in a row, Lacoste has hosted and become sponsor for the Desert Pool Party at the Coachella Valley Music and Arts Festival, which was a huge appeal for Generation Y. Lacoste created a place where celebrities, fashion lovers, bloggers and music fans attended the festival. Lacoste provided the guests full Access which was a really VIP experience. There were a wide range of engaging activities from mini golf to bocce ball which gave them the chance to choose whatever they want. They also involved social media by giving some premium items like flower crowns, garlands as long as they shared them on social media. ${ }^{7}$

Another good example is "Hermès' Festival Des Métiers". This luxury fashion house created a travelling cultural exhibition that gave consumers the chance to watch on Hermès' longstanding tradition of craftsmanship. Craftspeople were brought to explain their creative processes and techniques without giving away too many secrets. The exhibition featured a leather worker, a gem setter, a porcelain painter, a watchmaker, a silk printer, a saddler, a tie maker and a silk engraver. They showed various techniques that passed down from generation to generation to create Hermès products by hand. Visitors had the opportunity to rediscover this beautiful craftsmanship and learn the story of the products which gives another spirit to an object they have purchased. ${ }^{8}$

\footnotetext{
${ }^{7}$ http://www.bizbash.com/lacoste-live-desert-pool-party-coachella-right-trend-festival-lookslower/gallery/121019\#.VOYVUZGLTIU

${ }^{8}$ https://www.broadsheet.com.au/sydney/art-and-design/article/handcrafted-world-hermes
} 
"Porsche's Multi-Sensory Pop-Up" can also be given as a good marketing strategy. The luxury car brand installed a pop-up sensory experience in New York, visitors could immerse themselves in the stories and sounds of the luxury car brand's heritage. The experience was called "The Sound of Porsche." The event space was divided into three areas: The Sound Lab Virtual Drive Experience powered by Bose, The Media Station, and The Design Corner. The Sound Lab Virtual Drive Experience powered by Bose provided visitors to listen to the sound of model 911, by selecting melodies from urban to mountain pass. The Media Stations allowed the visitors to listen to a custom playlist created by Porsche. Lastly, The Design Corner gave the visitors the chance to participate in a creative process which enabled them to draw what was the meaning of the sound of Porsche to them or their vision of the future for Porsche. At this area, they could download their products through social media could have the chance to get a trip to Porsche Museum in Germany. Allowing them experience and get a feeling for the brand's heritage is a brilliant way to make young consumers feel they are part of something special. ${ }^{9}$

Airlines are also trying to keep up with new luxury consumers. The international airlines Emirates launched its first flight in Boston with a memorable event at the Boston Logan International airport. This opening included a speech by the Governor of Massachusetts, with performances by America's Got Talent favorite, iLuminate, and international superstar, Enrique Iglesias. To generate awareness among a younger audience, Emirates hosted an Instagram scavenger hunt raffles and delivered weekly clues with 15-second video posts. The program also included a Google Hangout interview with Emirates' president, Sir Tim Clark and the Wall Street Journal, which gave consumers face to face conversation with the executive for the first time. After this program flights from Boston sold out and for the brand it was a big opportunity to create equity. ${ }^{10}$

\section{CONCLUSION}

Marketing to members of Generation Y must be considered from a completely different perspective than the other generations in the past. Luxury is no longer only defined by price tag, label or design. Today, each product must tell a story and part of that story is relevance, ease of use and accessibility (AdAge Insights, 2012). Brands must find ways to give these young consumers information by using different and meaningful ways. This means not only using mobile devices like tablets and smartphones, but also through the in-store shopping experience. In addition, this generation would like to be given sharable information and to have the chance to share their thoughts and opinions with their friends and other loyal brand followers.

Generation $\mathrm{Y}$ is perhaps the most informed customers in the history of luxury, and they demand choice, à la carte shopping and easy ways to get exactly what they desire. The advantage of the evolution in luxury consumption is that this is a group that is easily persuaded but the question is whether brands will be active enough to be able to capture their attention.

Generation $\mathrm{Y}$ is still a novel market for luxury brands and is not currently the most profitable group, but it is the customer of the future. We know that Millennials are a crucial demographic to reach in order to meet the challenge of the evolving luxury sector in this age but the biggest challenge for brands is to determine how to achieve this. There are new rules and it's important for the luxury category to understand how to engage Millennials in the right way.

Even though Generation Y income is ascendant, they have a growing interest in it's really their sheer size coupled with a growing interest in "affluent items such as fashion and accessories, travel, and jewelry so that they become an incredibly important demographic for marketers. Although luxury brands are lucky with this rapidly growing group, it is also difficult to balance between exclusivity and selling more products. Generally luxury brands are preferred since they are hard to get so while trying to engage this audience they also have to consider their sales rate and profit. This presents a

\footnotetext{
${ }^{9}$ https://www.becausexm.com/blog/great-experiential-marketing-porsche-s-multi-sensory-pop-up

${ }^{10} \mathrm{http}$ ://www.emirates.com/kw/english/about/news/news_detail.aspx?article=1588170
} 
challenge but not impossible to manage balance for luxury marketers. For instance, if they sell their products as infrequent by using some ways like seasonal or limited-edition items, one-time offers and limited-time deals, they maintain exclusivity of their products without lessening the brand's value. Understanding their unique relationship with luxury items, native digital media habits and the way they share, discuss and make decisions about brands will most certainly be the key to driving growth of the entire luxury space going forward. Every legacy brand has to adapt or reinvent its values, offerings and go-to-market strategies to maintain relevance with an empowered, future biased Generation Y consumer as the driver of its core business (AdAge Insights, 2012).

It is important for marketers to understand these key points because it is obvious that Generation $Y$ will dominate luxury for the next decade. Their desires, needs and expectations are different from everything that has gone before but the rewards could guarantee that the brands which engage this generation prosper for years to come.

\section{REFERENCES}

AdAge Insights. Affluence in America: The Next Generation. Retrieved on 10.03.2016 from http://adage.com/images/bin/pdf/2012\%2012\%2010\%20affluence $\% 20$ in $\% 20$ america $\% 20$ gen $\% 20 y . p d$ f.

Akther, R. (2014). Redefining the Meaning of Luxury Goods: A Conceptual Paper. The Beagle: A Journal Of Student Research And Enterprise, 2(2). Retrieved on 20.04.2016 from https://journals.gre.ac.uk/index.php/beagle/article/view/145.

Barton, C., Haywood, J., Jhunjhunwala, P \& Bhatia, V. (2013). Travelling with Millenials. The Boston Consulting Group. Retrieved on 05.05.2016 from http://www.bcg.com/documents/file129974.pdf.

Bucuta, A. (2015). The Proceedings of the International Conference "Marketing - from Information to Decision": 38-47. Cluj-Napoca: Babes Bolyai University. Retrieved on 04.05.2016 from $\mathrm{http} / / /$ search.proquest.com/openview/8a24542e8ecce266f0d14da20e73eba2/1?pq-

origsite $=$ gscholar\&cbl $=1606336$.

Brun, A. \& Castelli, C., (2013). The nature of luxury: a consumer perspective. Retail \& Distribution Management, 41: 823-84.

Danziger, P.N. (2011). Putting the Luxe Back in Luxury: How New Consumer Values are Redefining the Way We Market Luxury . Paramount Market Publishing.

Danziger, P. (2004). Meet the young affluents: How the "Want-It-All, Want-It-Now" generation is changing the luxury market and what luxury brands need to do about it. A speech. Why people buy. Viewed 14.5.2016. http://www.whypeoplebuy.com/cms/Home Page/Speeches Presentations.php.

Deloitte. (2015). The luxury opportunity. Retrieved on 12.05.2016 from https://www2.deloitte.com/content/dam/Deloitte/uk/Documents/consumer-business/deloitte-ukconsumer-the-luxury-opportunity.pdf.

Deloitte. (2009). Generation Y: powerhouse of the global economy. Retrieved on 12.05.2016 from http://www2.deloitte.com/content/dam/Deloitte/us/Documents/human-capital/us-consulting-hcgenerationy-snapshot-041509.pdf.

DeVaney, S. A. (2015). Understanding the Millennial Generation. Retrieved on 17.04.2016 from http://connection.ebscohost.com/c/articles/110556940/understanding-millennial-generation.

Erickson, T. (2008). Plugged in: The Generation Y guide to thriving at work. Boston: Harvard Business Press.

Forbes, 2011. How The Uncertain Economy Is Changing The Definition Of Luxury. Retrieved on 04.03.2016 from http://www.forbes.com/sites/bluecarreon/2011/11/15/how-the-uncertaineconomy-ischanging-the-definition-of-luxury/.

Forbes, 2013. Luxury Consumers Value Products, Not Buying Experiences. Retrieved on 04.03.2016 from http://www.forbes.com/sites/arieladams/2013/05/23/luxury-consumers-valueproducts-notbuying-experiences/.

Gifts and Decorative Accessories. (2015). Generations Y and Z. Retrieved on 12.05.2016 from http://www.fluentgrp.com/wp-content/uploads/Gifts-Decorative-Accessories-Generations-Y-and-Zarticle.pdf. 
Gravett, L., \& Throckmorton, R. (2007). Bridging the generation gap: How to get radio babies, boomers, gen Xers, and gen Yers to work together and achieve more. New Jersey, The Career Press. Haataja, M. (2011). Attitudes of young people towards luxury products. Retrieved on 25.03.2016 from https://www.theseus.fi/bitstream/handle/10024/36814/Haataja_Maria.pdf? sequence $=1$

Hauck, W. E., \& Stanforth, N. (2007). Cohort perception of luxury goods and services. Journal of Fashion Marketing and Management, 11(2), 175-188

Hujic, L. (2005, December 7). Luxury leaders. Brand Papers. Retrieved from LexisNexis.

Huybers, C. (2011). The Recruitment and Retention of Generation Y. The Graduate School University of Wisconsin-Stout. Retrieved on 10.03.2016. from http://www2.uwstout.edu/content/lib/thesis/2011/2011 huybersc.pdf.

Immordino-Yang, M. H., Christodoulou, J. A., \& Singh, V. (2012), "Rest is not Idleness: Implications of the Brain's Default Mode for Human Development and Education". Perspectives on Psychological Science, 7(4), 352-364.

Kane,S.,(2011).GenerationY.About.com.LegalCareers.Viewed14.4.2016.http://legalcareers.about.com /od/practicetips/a/GenerationY.htm

Kapferer, J.N. \& Bastien, V. (2009). The Luxury Strategies. London, England: Kogan Page Ltd Kapferer, J. N. (2012a). The new strategic brand management. London: Kogan Page.

Kapferer, J. N. (2012b). Abundant rarity: The key to luxury growth. Business Horizons(55), 453- 462. Kapferer, J. N., \& Bastien, V. (2009). The specificity of luxury management: Turning marketing upside down. Journal of Brand Management, 16(5-6), 311.

Kim, Y.K. (2001) 'Experiential Retailing: An Interdisciplinary Approach to Success in Domestic and International Retailing', Journal of Retailing and Consumer Services, 8: 287-289.

Klapilová K. P.(2016). Generation Y Attitudes towards Shopping: A Comparison of the Czech Republic and Slovakia. Journal of Competitiveness, 8 (1), 38-54. Retrieved on 15.05.2016 from http://dx.doi.org/10.7441/joc.

Lancaster, L. C. \& Stillman, D. (2002). When generations Collide: Who they are. Why they clash. How to solve the generational puzzle at work. New York, Harper Collins Publishers, Inc.

Lazarevic, V. (2012). Encouraging brand loyalty in fickle generation Y consumers. Young Consumers, 13(1), 45e 61.

Makkar, M.(2014). Luxury for oneself or luxury for others? Exploring the underlying emotions behind inconspicuous luxury consumption. Auckland University of Technology. Retrieved on 28.03.2016

from

http://aut.researchgateway.ac.nz/bitstream/handle/10292/8649/MakkarM.pdf?sequence=1.

Martin, C. A. \& Tulgan, B. (2001). Managing generation Y. Massachusetts, HRD Press.

Miller, C. (2015). How Generation Y Could Tip the Invisible Hand of the Luxury Marketplace. Retrieved on 15.05.2016 from http://www.slideshare.net/CarolineMiller01/miller-gen-y-thesis-slidesmarch-5-jan-edit/30.

Mityra, S. S. (2013). Engaging the Next Generation of Luxury Buyers. Social Technology Quarterly. Retrieved on 04.05.2016 from http://www.slideshare.net/Kuliza_Research/engaging-the-nextgeneration-of-luxury-buyers.

Muhammad, I. \& Ng, W. (2002). The Importance of Entertainment in the Shopping Center Experience: Evidence from Singapore. Journal of Real Estate Portfolio Management: 2002, Vol. 08, No. 3, pp. 239-254.

MSLGroup PBJS. Millenials \& The New Luxury. Retrieved on 17.04.2016 from http://www.slideshare.net/PBJS/millennials-the-new-luxury.

Noble, S. M., Haytko, D. L., \& Phillips, J. (2009). What drives college-age Generation Y consumers? Journal of Business Research, 62(6), 617e628.

Nueno, J. L., \& Quelch, J. A. (1998). The mass marketing of luxury. Business Horizons, 39 (6), 61-68 Okonkwo, U. (2005). Can the Luxury fashion brand store atmosphere be transferred to the Internet? Retrieved on 10.03.2016 from $\mathrm{http} / / \mathrm{www}$. brandchannel. com/images/papers/269_Lux_Goods_Online. Pdf.

Okonkwo, U. (2007). Luxury Fashion Branding: Trends, Tactics, Techniques. New York: Palgrave Macmillan.

Okonkwo, U. (2009). Sustaining the luxury brand on the Internet. Journal of Brand Management, $16(5), 302-310$. 
Okonkwo, U. (2010). Luxury Online: Style, Systems, Strategies. New York: Palgrave Macmillan.

Orrell, L. (2007). Millennials incorporated: The big business of recruiting, managing and retaining the world's new generation of young professionals. United States of America, Intelligent Women Publishing.

Park, J., D. Gürsoy, (2012). Generation effects on work engagement among U.S. hotel employees, International Journal og Hospitality Management, article in Press.

Parment, A. (2013). Generation Y vs. Baby Boomers: shopping behavior, buyer involvement and implications for retailing. Journal of Retailing and Consumer Services, 20(2), 189e199.

Pine, B. J., II, \& Gilmore, J. H. (2011). The experience economy. Harvard Business Press.

Prendergast, G. \& Wong, C.,(2003). Parental influence on the purchase of luxury brands of infant apparel: an exploratory study in Hong Kong. Journal of Consumer Marketing, 20(2): 157-169.

PrincetonOne, White Paper. Understanding Generation Y. Retrieved on 12.05.2016 from (http://www.princetonone.com/news/PrincetonOne\%20White\%20Paper2.pdf.

Reilly, P. (2012). Understanding and Teaching Generation Y . English Teaching Forum. Number 1. Retrieved on 10.03 .2016 from https://americanenglish.state.gov/files/ae/resource files/50 13 reilly.pdf.

Reisenwitz, T. \& Rajesh Iyer, (2009). Differences in Generation X and Generation Y: Implications for the Organization and Marketers. Retrieved on 12.05.2016 from http://www.mmaglobal.org/publications/MMJ/MMJ-Issues/2009-Fall/MMJ-2009-Fall-Vol19-Issue2Complete.pdf\#page $=112$

SCB Economic Intelligence Center. (2014). Capturing Thai Gen Y consumers. . Retrieved on 25.03.2016

from

https://www.scbeic.com/en/detail/file/product/276/e1y9e19c4h/Insight Eng GenY 2014.pdf.

Schewe, C. D. and Meredith, G., 2004, - Segmenting Global Markets by Generational Cohorts: Determining Motivations by Agell. Journal of Consumer Behaviour, Vol.4, No.1, pp 51-63

Silverstein, M. \& Fiske, N. (2008). Trading up. Why consumers want new luxury goods and how companies create them. Third edition. New York: Portfolio.

Solomon, M. (2014). Your Customer Is the Star: How to Make Millennials, Boomers and Everyone Else Love Your Business. Forbes Signature Series.

Solomon, M. R. (2004). Consumer Behavior - Buying, Having, and Being (6th Ed.). Upper Saddle River, NJ: Prentice Hall.

Solomon, M. (2014). 2015 Is The Year of the Millennial Customer: 5 Key Traits These 80 Million Consumers Share. Retrieved on 14.04 .2016 from http://www.forbes.com/sites/micahsolomon/2014/12/29/5-traits-that-define-the-80-million-millennialcustomers-coming-your-way/\#18e9bc722a81.

Stella, S.L.M. (2011). Luxury Generation Gap? A Comparison between Generation X and Y. Cambridge Business \& Economics Conference. Retrieved on 10.04.2016 from http://www.gcbe.us/2011 CBEC/data/So\%20Lai\%20Man,\%20Stella.doc.

Sullivan, P., Kang, J., Heitmeyer. (2012). "Fashion İnvolvement and Experiential Value: Gen Y Retail Apparel Patronage", The International Review of Retail, Distribution and Consumer Research, 22 (5), 462-465.

Sun, M.W. (2011). Consumption of luxury fashion brands: The Motives of Generation Y Consumers in China. Retrieved on 12.04.2016 from http://aut.researchgateway.ac.nz/handle/10292/1335.

Talbott, S. (2012) Generation Y and Sustainability. University of Tennessee Honors Thesis Projects. http://trace.tennessee.edu/utk chanhonoproj/1498

The Gold Paper. New Millenial Luxury. Retrieved on 17.04.2016 from http://goldpaper.somewhat.cc/gold-paper-book.pdf.

Vigneron, F., \& Johnson, L. W. (2004). Measuring perceptions of brand luxury. The Journal of Brand Management, 11(6), 484-506

Walley, K., Custance, P., Copley, P. \& Perry, S., 2013. The key dimensions of luxury from a UK consumers' perspective. Marketing Intelligence \& Planning, 31(7): 823-837.

Wiedmann, K., Hennigs, N., \& Siebels, A. (2007). Measuring consumers' luxury value perception: A cross cultural framework. Academy of Marketing Science Review, 7 (7), 333-361. 
The Turkish Online Journal of Design, Art and Communication - TOJDAC July 2016 Volume 6 Issue 3

Wilson, J. J., 2014. Inconspicuous Branded Consumption Is the New Business Buzzword in Retail. Retrieved on 19.04.2016 from http://www.huffingtonpost.co.uk/jonathan-ajwilson/inconspicuousbranded-con b 4734255.html.

http://www.mediapost.com/publications/article/258737/hey-luxury-marketers-the-multiculturalmillennia.html. Retrieved on 14.05.2016. 